\title{
Party Work as Political Participation: \\ The Vocational Motivations of Labour Party Employees
}

Justin Fisher (Brunel University) \& Paul Webb (University of Sussex)

6,309 Words Plus 5 Tables 


\title{
Party Work as Political Participation: The Vocational Motivations of Labour Party Employees ${ }^{1}$
}

\begin{abstract}
Party employees are an under-researched group in political science. This article begins to address this oversight by examining Labour Party employees using new qualitative and quantitative data. It argues that party employment should be regarded as a form of political participation and as a consequence, existing models of political participation can be utilised to help explain why people work for political parties. After testing these propositions, the article concludes that existing models are indeed helpful in explaining the motivations for party employment.
\end{abstract}

\section{Introduction}

In the past decade, a great deal of research has enhanced our knowledge about various aspects of political parties. Thus for example, Seyd and Whiteley have made path-breaking studies of party members (Seyd \& Whiteley, 1992; Whiteley et al, 1994); Denver and Hands (1997) have made a significant contribution to our knowledge as to how parties organise constituency campaigns; Norris and Lovenduski (1995) have analysed the attitudes of MPs and candidates, whilst Baker et al (1999) have focussed on MPs' attitudes towards Europe. In addition, a plethora of volumes has been published on political parties in general, focussing on their history, ideology and organisation. All these have made welcome additions to the field. However, none has examined in any depth a vital component of parties: their employees. 
Notwithstanding Rose's brief survey (1974), this lack of research into party staff constitutes a significant omission by political scientists. Moreover, the significance of this is amplified by the fact that party employees may well be becoming more important in the overall composition of parties. Not only are party members apparently 'de-energised' (Seyd \& Whiteley, 1992; Whiteley et al, 1994; Whiteley \& Seyd, 1998), but the ratio of party employees to members has changed significantly. Thus, in 1964 the ratio was one Labour employee to every 2786 individual members of the Labour Party. By 1998, the ratio was 1:1231, a net change of 56\% (Webb \& Fisher, 2001: 5). For the Conservatives, the change has been even more significant. Over the same period, the ratio of employees to members fell from $1: 3176$ to $1: 1030$, a change of $68 \% .^{2}$ In short, individual party membership has broadly declined, individual members' activism is declining and the ratio of staff to members is greater. Undoubtedly then, parties have come to rely increasingly on paid staff; not only on account of the decline in voluntary labour, but also to engage in more elaborate, sophisticated and regular election campaigning. As Rose (1974: 167) remarks: 'Without full-time officials, national parties would be the opposite of nationwide organizations....full time officials are needed to ensure continuity in organization across time and space.' Party employees therefore matter and are worthy of study. In a separate article we examine party employees in the context of debates about party professionalization (Webb \& Fisher, 2001). Here, we are concerned with analysing the reasons for engaging in party employment.

\section{Data}

This article draws on a blend of new quantitative and qualitative research conducted by the authors on Labour Party employees. ${ }^{3}$ Data have been gathered in two ways. First, we conducted a series of interviews with senior officials (mainly unit heads) at Millbank and the PLP office at Westminster. These qualitative data provided broad overviews of the 
experience of party employment from a variety of sections within the central party, including what might be called the 'campaigning' units such as press and policy, as well as with 'routine administration' sections such as the finance and conference units. This qualitative research was complemented by a closed-ended survey of all staff at Millbank, the PLP and the regional offices. We generated a sample of 96 responses (approximately 30\% of the Party's present staff establishment), ${ }^{4}$ which is broadly representative both spatially and across the grade structure. ${ }^{5}$

\section{Party Employment and Political Commitment}

An initial question which needs to be asked regarding party employees is whether political commitment is a pre-condition of employment. For example, Jordan and Maloney (1997) found that amongst interest group employees, particularly those in marketing, commitment to the group's cause was a secondary factor in recruiting staff compared with a proven track record of success in marketing. They quote job advertisements where previous experience in similar organisations was not required. Rather, the main focus of an employee was to maximize the group's income. Given that the salaries quoted for such positions were highly competitive, it would seem reasonable to conclude that political commitment is not a prerequisite for employment in these groups, and that employees may well be motivated primarily by the financial rewards associated with such posts.

Our study of Labour employees suggests a rather different picture - that party staff are also voluntary activists in the conventional sense. Some $88 \%$ of the sample were party members prior to taking up a paid position within the party organisation and, as Table $\mathbf{1}$ shows, some two-thirds of these claimed to be 'very active' in their local parties. What is more, it is apparent that party employees have been quite heavily involved in elective politics, 
especially at the local level (Table 2); by contrast, only $15 \%$ of members claimed to have stood for public elective office at any level (Seyd \& Whiteley 1992: 95, 234), and only 11\% claim to have stood in the five years preceding $1997 .^{6}$

[Table 1 About Here]

[Table 2 About Here]

Indeed, it is interesting to draw a general comparison with activism levels of party members, although this is not easily done since our indicator of activism is not strictly comparable with those used in other studies; however, there is basic evidence to suggest that party employees may be well above average in terms of their commitment to party activity. For instance, if we take the most minimal indicator of activism in Seyd and Whiteley's most recent survey of Labour Party members (conducted in 1997) - contact with other local activists - we find that only $34 \%$ said they had had frequent contact in the last year. Of course, this is not directly comparable with the subjective judgement of $86 \%$ of our sample that they were active or very active prior to joining the party staff. That said, the qualitative interviews with elite staff tend to display surprisingly rigorous definitions of what it meant to 'be active':

I don't necessarily mean being a local councillor but if someone has been in the Labour Party for 5 years and when you say 'how do you find canvassing, leafleting and campaigning'?, and they clearly haven't done it, I don't call that activism. $^{7}$

To me, 'active' would be someone who regularly attends branch meetings. ${ }^{8}$ 
Thus, even though the Party may be increasingly inclined to recruit staff according to strictly 'professional' or 'vocational' criteria (Webb \& Fisher, 2001), it remains the case that most come into their jobs with a background of activism. Interestingly, there appears to be some relationship between age and activism; that is, while fully $97 \%$ of staff over the age of 40 claim to have been activists prior to party employment, just $80 \%$ of those under 40 (and $75 \%$ of those under 30) did. It should also be noted that once a party member joins the staff, this may compress the amount of time and commitment that an individual has for voluntary activism in a local constituency party. As one Millbank unit head put it:

Before (I became a party employee) I was a branch secretary and so I was involved in all the decisions, making sure we got guest speakers to meetings and things like that. I would definitely say that my activism has waned since I came here...I think there are certainly plenty who remain very active; there are some who are councillors, some who run their own constituencies, some who are Chair, some who go out canvassing quite regularly. I think that it is quite a mixed bag, but I think that there is a cycle that you go through where you peak quite early on when you work for the Party, but then to some extent it tends to wane a bit as you are pursuing your activism in your job anyway. ${ }^{9}$

\section{Explaining Party Employment}

Given the information cited here, it seems reasonable to consider party employment as a form of political activism. Typically, research focuses on forms of voluntary participation in which activists receive no pay for the role they play (as interest group or party members, protestors, etc.). However, there is no logical reason why paid employees should not also be considered. After all, it is orthodox to describe political participation in terms of a scale of activity 
running from those forms which require least commitment from a citizen (such as signing petitions), to those which require greatest commitment. At the top end of this scale lies elective public office (Parry et al 1992; Seyd \& Whiteley 1992), which, except for most local councillors, is clearly a form of paid professional political participation. As we have seen, most employees are members prior to employment and are probably more active that other members; their employment might plausibly be seen as an extension of this activity, especially since, for some, it replaces some of their previous unpaid activity. Unlike the interest groups discussed by Grant and Maloney, party employees are not just 'in it for the money'.

If party employment can be regarded as an extension of conventional activism, it follows therefore that it is reasonable to attempt to explain this form of activism utilising established models of political and party participation. By doing so, we can offer some insight into the motivations and aspirations of contemporary Labour Party staff. We do this by reference to two such models: the individual resources model and the general incentives model.

\section{Individual Resources}

The individual resources approach has been borne out by many studies which suggest that those with greater personal resources, such as education and the other advantages brought by higher social status, are more likely to participate in political activity (see, for example, Parry et al 1992). Seyd \& Whiteley (1992: 71-73, 98-99) demonstrated this pattern with regard to Labour members and voters: thus, those of a higher social status proved more likely to be members and activists, notwithstanding the Party's supposed 'proletarian' traditions. In our case, we can extend this idea to suggest that higher social status is a correlate of and stimulus to party employment. 
Referring to Table 3 it is easy to see that this is indeed the case in respect of class, education and trade union membership. Although members have a greater sense of class identification than employees, employees are more likely to be middle-class. Moreover, employees tend to be well-educated - significantly more so than party members or voters; fully $71 \%$ have a degree or higher qualification, compared with $21 \%$ of members, a fact which suggests that employees are likely to enjoy a higher sense of political efficacy. Finally, we have already seen that employees are likely to have trade union membership, a 'resource' in the context of the Labour Party since it provides a route into the Party through knowledge of the values, ethos, structures and procedures of the movement. That said, it must be noted that only a small minority actually worked for a union prior to coming to the Labour Party.

\section{[Table 3 About Here]}

Interestingly, in respect of all of these social background variables we find some evidence once again of a small but distinct age effect. Thus, $86 \%$ of those under 31 are union members whereas all older staff are; $15 \%$ of those aged 40 and older were formerly union employees, but only $11 \%$ of those under 40 years of age were; $57 \%$ of those over 40 are graduates, while fully $80 \%$ of those under 40 were; and $31 \%$ of those over 40 regard themselves as working class, but only $22 \%$ of the under-40s do. The only variable where resources do not appear to make a difference is ethnicity; here, the profile is virtually identical across employees, members and voters. So we gain an impression of a party staff in which middle class status and education are important conduits to recruitment, while a history of working for the unions still has minor, but probably diminishing significance. 


\section{General Incentives}

The second model is informed by the work of Seyd \& Whiteley. Developed to account for party activism, it embraces the notion that the Olsonian model of rational individualism, 'while plausible and insightful', is too narrowly focused to give an adequate account of political participation (Seyd \& Whiteley 1992: 59). Their approach accepts the central insight of rational individualism that individuals respond to incentives in politics as elsewhere in life, but argues that these incentives are far more varied than rational choice theorists generally assume. While data constraints make it impossible for us to offer a rigorous multivariate test of the general incentives model in respect of party employment, ${ }^{10}$ it is nevertheless possible to offer some insight into the importance of the various incentives which motivate individuals to join the party staff. There are three fundamental types of incentive on which we focus here:

Rational individualist incentives: These are derived directly from conventional rational choice explanations for participation. They flow in particular from the ideas of Olson (1965) who conceived of participants as involved in a process of assessing benefits and costs. First, it includes the calculations which individuals make about the likelihood of their participation having any significant influence on collective outcomes. It is therefore useful to consider how far party staff feel that their work affects the Party's chances of success in achieving its goals. Second, it includes the selective benefits that may accrue as a result of participation. From this perspective, for instance, it is conceivable that party employees see their work as a step on the path either to future elective public office or to a high-ranking position within the national party bureaucracy which carries with it the promise of prestige, influence and high remuneration. It should be borne in mind that there are two types of selective incentive those concerned with the outcomes of party employment (such as the furtherance of career 
ambitions) and those concerned with the processes involved in party employment (such as the intrinsic satisfaction derived from such work). Finally, such selective individual benefits as well as political efficacy must be offset against any potential costs associated with pursuing party employment.

Altruistic incentives: The essence of this idea is that individuals might be motivated to work for the Party by altruistic moral imperatives, as expressed by commitments to broad underlying values. Thus:

When faced with the possibility of free-riding on the efforts of others, group members ask themselves the question 'What if everyone did that?'; and since the answer is that the collective good would not be provided if everyone tried to free-ride, they choose to participate. (Seyd \& Whiteley 1992: 63)

Collective incentives: This approach draws upon the idea that commitment to solidaristic policy goals may promote participation. 'The key to understanding this idea is recognition of the fact that individuals can put themselves in the place of the group, and think about group welfare rather than just their own individual welfare' (Seyd \& Whiteley 1992: 61). Such collective incentives as a belief that the Labour Party can make a difference to, say, the provision of public services or the just distribution of resources in society, might motivate individuals to work for it as paid employees. Unlike conventional rational choice models, the benefits of such policies are non-excludable. The distinction between altruistic and collective incentives may seem quite fine, but whereas the latter is concerned with specific policy goals, the former derives from the conviction that all group members must participate if a good is to be provided. 
One way of evaluating the usefulness of this explanation is to compare the policy orientations of party staff and ordinary party voters; if it is to be in any sense persuasive then we should expect to find evidence that Labour employees are more committed to certain party policy goals than ordinary voters are. Indeed, it may even be true that employees are still more committed to collective policy goals than party members and activists.

Seyd \& Whiteley were not the first to apply incentive-based analysis to party activism, nor to question the utility of narrowly cast rational choice models for these purposes. Wilson (1973) advocated a series of incentives. Material and specific solidary incentives equate broadly with selective benefits, whilst recognising a differentiation between material (material) and non-material (specific solidary) incentives. Collective solidary incentives equate broadly with Seyd and Whiteley's selective process incentives. However, Wilson also develops purposive incentives described as the 'intangible reward that derive from the sense of satisfaction of having contributed to the attainment of a worthwhile cause. They depend crucially on the stated objectives of the organization and are general in that any member of such a group can derive some satisfaction from group efforts even if he himself contributed in nothing but his name' (1973: 34). The problem here, as we see it, is that while Wilson's designation 'purposive incentives' clearly conforms closely to Seyd and Whiteley's notion of collective incentives, it does not allow us to distinguish personal efficacy (see below) in the same way. Thus, whilst Wilson's analysis undoubtedly serves as an informative and useful point of embarkation for the analysis of participation in party politics, we prefer the more developed formulation suggested by Seyd \& Whiteley since it allows a more subtle differentiation between the various types of incentive. 
In Tables 4-5 we report the distribution of our sample's responses to questions designed to tap the variety of incentives outlined in the foregoing discussion. To reiterate, for lack of any comparator with party staff, it is impossible to offer a true multivariate test of the general incentives model, but the results reported in these tables provide some insight into the factors which motivate people to work for the Labour Party. We start with rational incentives, which are considered in Table 4: the chances of influencing collective outcomes, the costs to the individual associated with working for the Party, and the selective outcome and process benefits to be derived from such employment.

First, a sense of personal political efficacy is a significant element of participation calculations in that it would seem irrational (other than for purely altruistic reasons) for individuals to participate in any activity they see as unlikely to have any impact on the achievement of policy objectives. Table 4 shows that personal political efficacy is very high: some 9 out of 10 Labour staff believe that they can influence the Party's chances of success through their work. This is consistent with the possibility that significant numbers of staff regard their work as important to the achievement of collective policy objectives. Indeed this proportion is notably high. Whilst $76 \%$ of party members feel that they can have a real influence on politics, ${ }^{11}$ the likelihood is that for employees - especially at the centre - this sense of personal efficacy is more likely to be satisfied. Thus, whilst the sense of efficacy amongst members is (pleasingly) high, it should be less of a surprise that the score for employees is higher. Moreover, the high sense of efficacy is likely to offset to a greater extent the associated costs of participation (see below). If so, the 'paradox of participation' (where costs outweigh benefits) is less likely to occur even prior to considering the selective benefits which might accrue. 
Next, we assume that a rational individualist actor will calculate the costs as well as the benefits of any action, and it seems that Labour staff are acutely aware of the opportunity costs of their occupation: $86 \%$ think they would be better paid if they did similar work for another employer. The survey data are strongly supported by the qualitative material on this point:

Generally speaking I suppose my staff could command better salaries working elsewhere, working in local authorities, working in lobbying firms. ${ }^{12}$

Salaries are the big problem, particularly in the area that I head up. They (the staff) are all commercial so their skills are fairly sellable, whether it's for a charity or commercial. So the factor that people leave for is the salary. Another is the lack of movement...the trouble with it is in terms of pay you can't move on very quickly. If you are a bog-standard Press Officer you're not going to really earn a lot of money and you tend to inch up the scale, so you're never going to be rich and famous. That's the problem really. When they come through the election, if there is the possibility to work somewhere else that is political, a bit more exciting and they get paid more, then they might take it. ${ }^{13}$

In addition, the prospects for long-term career progression through the Labour Party are generally poor. Its organisational structure is relatively 'flat', a factor which almost certainly contributes to a comparatively high turnover of staff; a phenomenon also observed in the United States by Wilson (1973: 108): 
I think that if people do start here thinking this is where they will have a career then they soon realise that it isn't:.it's a place to buy into your job, do your job and then perhaps move on. ${ }^{14}$

I think that if you are purely someone who is committed to working for the Party there comes a point when...there aren't many avenues for you and you would have to look outside the Party in order to stretch yourself...If you're working for a senior politician or working as an administrator here, you could work your way up to working on campaigns, then you could go to membership, become a Unit head. But if you're working for a politician or as a political advisor there are very few places you can go. ${ }^{15}$

There is, then, a strong awareness of the opportunities for individual betterment which may be foregone in opting to work for the Party - something previously noted in party employees by Rose (1974: 168). A further, perhaps less tangible, cost of party work is the relatively diffuse sense (manifested by $61 \%$ of the sample) that it is undervalued by party elites. That said, while some employees realise that there is little prospect of long-term progression within the Party, they may well regard party work as invaluable and interesting experience for a defined period of their working lives.

...there are those with bright ambitions that see this as a help or steppingstone and a good experience. I do say to people coming in that the kind of experience you get at the Labour Party is excellent training for almost any kind of work. You meet a wide variety of different kinds of interesting people, doing a variety of roles that benefit. ${ }^{16}$ 
As Table 4 also attests, there is no doubt that many employees can point to a range of selective benefits associated with their jobs. First, there are the selective process incentives, which make the work intrinsically satisfying. Three-quarters of the sample consider party work to be much more fulfilling than alternative employment, and most (nearly 9 in 10) recognise the benefits of working with like-minded people. Indeed, the likelihood of meeting like-minded people is considered to be even greater among employees than it is among members, only $63 \%$ of whom agreed that activism led to meeting interesting people. ${ }^{17}$ Furthermore, the prospect of working for an organisation that values initiative, dynamism and professionalism is an attraction for some.

Trade unions pay much more than us....(but) the Labour Party would be at the top of the pecking order. We would have people applying from trade unions or other government associations or from policy units in local councils or whatever. They...might take a salary cut as well in order to work here, as they see it as more prestigious. They find that they are able to use their skills better, develop their skills better, and find it more interesting. ${ }^{18}$

Second, there is evidence that selective outcome incentives may figure in the minds of some employees as a motivating factor. This shows, for instance, in the perception of around half our respondents that working for the Party is favourable to their chosen career. In this context, it is worth observing that, even though it may not be a consideration when party employment commences, a number of former employees have gone on to work either in wellpaid or prestigious political jobs, especially in lobbying (described as 'the biggest draw' by one unit head at Millbank). Not that this phenomenon draws universal approval; nakedly self- 
interested careerism may be frowned upon, which in itself points to the fact that staff are not driven entirely by personal career goals (Webb \& Fisher 2001: 18). Nevertheless, there is enough evidence in Table 4 to confirm that some mileage exists in the idea of selective outcome incentives influencing Labour staff. For instance, as we have seen (Table 2), the proportion of our sample who aspire to elective public office of one kind or another is certainly impressive; while two-fifths see themselves as having the necessary qualities to become parliamentarians, one-fifth admit to parliamentary ambitions and significant proportions aim to become MEPs or local councillors. Qualitative interviews confirm the belief on the part of some senior staff that party employment is regarded as a stepping-stone to elective office in certain quarters (Webb \& Fisher 2001: 23).

Even so, the majority of party employees almost certainly do not have such vaulting ambitions, an attitude exemplified by the following comment:

We are background people - you might use the term 'civil servants'. No, I think over my dead body would I be going into politics! I think being an elective representative for the Party is the worst job in the world and is not something I covet at all. If they want to do something they can do it up there but I like to be behind the scenes getting things done. ${ }^{19}$

This points us to the importance of non-selective benefits in motivating party employment. Table 4 also reports on altruism, which does not sit within conventional rational choice models. We asked staff about one type of altruistic motivation, the importance of party work to the fabric of democracy: some two-fifths see their work as significant in this respect, though interestingly, a comparison of the proportion who hold the view that democracy is 
enhanced by their efforts with those that seek selective benefits suggests that altruism may not be the most significant incentive.

\section{[Table 4 About Here]}

What then of collective policy incentives? Seyd and Whiteley (1992: 56-85) demonstrated that these are an important component of the decision to join the Labour Party: that is, a greater commitment to certain party policy goals is associated with a great propensity for membership. Similarly, the qualitative data suggest that collective incentives might be an important factor in the decision to work for the party.

I would say that the first reason, 9 times out of 10, is the feeling that you work for something that you believe in. I know that that would be my motivation and I would be very surprised if you found anyone in whom it wasn't the primary motivation. You can see that this organisation is not a 9 to 5 place: people work late, they work weekends. Many organisations that don't have such a strong belief structure would not sustain that (workload)...You can see by the amount of time and effort that they (party staff) put in that that is their primary motivation. In some cases I would say that it is mixed in with the sense that they are associated with members of the State, and in some cases it is a stepping stone to their ambitions to become other things. But I would say that overwhelmingly it is about getting a warm feeling from doing what you believe in and seeing the tangible outcomes. ${ }^{20}$ 
Table 5 provides some insight into collective policy incentives in respect of party employees. Seyd and Whiteley tested their general incentives model of party membership by comparing members with other social groups such as party voters; here we attempt to replicate this approach by comparing the collective policy orientations of party employees with those of Labour members, voters and MPs respectively. ${ }^{21}$ For each of the policy dimensions reported in Table 5 except Europe, the more positive the value reported in a cell, the more left-wing, libertarian or postmaterialist the group in question is overall; on the question of European integration, the lower the value, the more pro-European the group.

Scrutiny of the Table reveals that party employees have an attitudinal profile which stands out from comparator groups in a number of respects. While they are similar to Labour MPs and party members in being significantly more pro-European than Labour voters, they are considerably more postmaterialist and libertarian than any of the comparator groups; and they are also notably more right-wing than any of the comparators in the Table (though they remain comfortably left-of-centre on the whole). On the face of it, this is probably an unsurprising profile for a sample of New Labour staff, although we suspect that party personnel may be more libertarian, and perhaps more postmaterialist, than their political leaders (Webb 2000: 123). However, the pro-European and centre-left stance is entirely consonant with Tony Blair's leadership (Webb 2000: 96-98).

\section{[Table 5 About Here]}

Given the traditional salience of Left-Right issues in party competition in Britain (Webb 2000: 112), the employees' location on this dimension is perhaps deserving of special comment. Seyd and Whiteley's general incentives theory suggested that members would 
express greater support for collective policy goals than party voters would, an expectation generally confirmed by the evidence (1992: 69-70). A simple extension of this approach to party employees might seem to imply that they choose to work for the Party because they are yet more committed to its policy goals than even the members, but if by 'more committed' we mean more left-wing, then clearly the data show this not to be the case. In fact, their comparatively right-wing location puts one in mind of John May's well-known 'law of curvilinear disparity' (1973) and suggests that party staff may resemble party leaders in being more concerned with vote-maximising or office-seeking motivations than with policy-goals.

This idea is premised on the notion that different strata within political parties have different incentives and motives. While leaders are driven primarily by vote-maximising imperatives, 'sub-leaders' (such as grass-roots activists) are largely motivated by 'purposive' incentives like the desire to influence party policy or candidate-selection. Thus, while vote-maximising or office-seeking leaders can be expected to seek out policy positions which approximate those of the median voter as nearly as possible, members may be more concerned to maintain ideologically 'pure' (which is to say radical) positions. A further party stratum of 'nonleaders' includes individuals who are not formally members at all, such as supporters and sympathisers in the electorate; these are hypothesised by May to be the most ideologically moderate of the strata. Our data imply the possibility that party staff (a stratum rarely if ever taken into account in discussion of ideological disparities between strata) may be closely akin to frontbench political elites in being driven primarily by electoral or office-seeking imperatives.

However, a number of factors suggest an alternative interpretation. For one thing, spatial location along a Left-Right attitudinal scale should not necessarily be regarded as a good 
indicator of intensity of commitment to policy goals; is it not possible that ideological centrists could be just as keenly concerned about their preferred policy objectives as radicals? If so, then we should have to concede that collective policy incentives could indeed be an important source of motivation for party staff, just as the qualitative data suggest. In any case, even if simple spatial location is a legitimate way of measuring intensity of policy commitment, it should not be forgotten that party staff are more radical than any comparator group in respect of the three non-Left/Right ideological dimensions.

Moreover, three other pieces of evidence this research has uncovered should not be disregarded at this point in the discussion: first, it really is striking how emphatically senior staff state that employees are often motivated to work for the Party because of commitments to policy goals; second, we have encountered overwhelming quantitative evidence that staff are acutely aware of the opportunity costs associated with their jobs, so why should they work for the Party unless driven in part by altruistic or collective policy imperatives? And third, it is equally obvious that party personnel generally see their work as important to the success of the Party (though it is true that we cannot be entirely sure if respondents had electoral or policy success uppermost in their minds when answering this question ${ }^{22}$ ). In the light of these points, it seems improbable to us that collective incentives do not play some kind of significant role in explaining people's decisions to become party employees: although the relative importance of collective and selective incentives (and altruistic motivations) is impossible to gauge given that our data constraints prevent a true multivariate test of the general incentives model. 


\section{Conclusions}

Party employees matter and matter increasingly. But why do they work for parties? One way of answering this question is to examine employment as a form of participation - something that has not previously been done. On the evidence presented here, we are confident that party employment can be said to be a form of political participation. Labour employees are, on the whole, previously active in conventional voluntary terms. They continue to be active and see employment as an extension of that activity. Moreover, their definitions of 'active' are fairly rigorous. All of this suggests that our initial claim, that party employment should be seen in these terms, provides a reasonable basis on which to proceed to the second stage of analysis. Since we can regard employment as a form of participation, it is legitimate therefore to apply conventional models of participation to establish the correlates of such activity.

In the traditional resources model, our data show that employment as a higher form of participation is consistent with other research - namely that that those with greater resources are likely to participate more actively. Labour employees generally have a high level of the requisite resources. In terms of incentives-based models, we show that these too are applicable. Both the conventional Olsonian models and the more inclusive models devised by Seyd and Whiteley show that incentives are significant for the decision to embark upon and remain in party employment. Nevertheless, it is also worth noting that incentives that sit within more conventional Olson models are apparently more significant for employees than for members. Employees have a very strong sense of personal efficacy, are aware of the costs involved in their participation and are also cognisant of the selective benefits which accrue. They are, to some extent, rational actors. 
Yet, just as with members, rational choice models alone do not provide a sufficiently comprehensive account of the incentives for activism. Collective incentives also matter. Our examination of the quantitative data suggests initially that views on libertarian-authoritarian issues, postmaterialism and Europe all provide a strong prompt to embark upon this form of participation. The addition of qualitative data suggests that collective incentives of all shades are significant. Moreover, one should be wary of the simplistic logic that only radicals maintain strongly held convictions. Finally, the impact of altruism should not be overlooked. All in all, this demonstrates that models of these kinds are useful in answering addressing questions such as why people work for organisations like political parties. Of course, the data analysed here pertain only to Labour employees. But given the applicability of the models employed here, which have been used to examine activism in other parties (Whiteley et al, 1994), there is reason to suspect that what may be true of Labour employees is likely to true elsewhere. 


\section{References}

Baker, D., Gamble A., Seawright D. \& Bull K. (1999) 'MPs and Europe: Enthusiasm, Circumspection or Outright Scepticism?' in Fisher, Cowley, Denver \& Russell (eds) British Elections \& Parties Review Vol. 9 (London: Frank Cass) pp. 171-85.

Denver, D \& Hands G. (1997) Modern Constituency Electioneering (London: Frank Cass).

Heath, A, Evans G. \& Martin J. (1993) 'The measurement of core beliefs and values: The development of balanced socialist/laissez-faire and libertarian/authoritarian scales' British Journal of Political Science 24, pp. 115-58.

Jordan, G. \& Maloney, W. (1997) The Protest Business (Manchester: Manchester University Press).

Norris, P \& Lovenduski J. (1995) Political Recruitment (Cambridge: Cambridge University Press).

May, J.D. (1973) 'Opinion Structure of Political Parties: The Special Law of Curvilinear Disparity,' Political Studies 21: pp. 135-51.

Mueller, W.C., \& Strom K. (1999) Policy, Office or Votes? How Political Parties in Western Europe Make Hard Decisions (Cambridge: Cambridge University Press).

Olson, M. (1965) The Logic of Collective Action. Cambridge, (MA: Harvard University Press).

Parry, G, Moyser G. \& Day N. (1992) Political Participation and Democracy in Britain, (Cambridge: Cambridge University Press).

Rose, R. (1974) The Problem of Party Government (London: MacMillan Press).

Seyd, P. \& Whiteley P. (1992) Labour's Grass Roots (Oxford: Clarendon Press).

Webb, P. (2000) The Modern British Party System (London: Sage Publications).

Webb, P. \& Farrell D. (1999) 'Party Members and Ideological Change' in Evans \& Norris (eds) Critical Elections (London: Sage) pp. 44-63.

Webb, P. \& Fisher J. (2001) Professionalizing the Millbank Tendency: The Political Sociology of New Labour's Employees (Sussex: Sussex Working Papers in Contemporary European Studies).

Whiteley, P. \& Seyd P. (1998) 'The Dynamics of Party Activism in Britain: A Spiral of Demobilization? British Journal of Political Science 28: pp. 113-51.

Whiteley, P., Seyd P. \& Richardson J. (1994) True Blues (Oxford: Clarendon Press) 
Wilson, J.Q. (1973) Political Organizations (New York: Basic Books). 
Table 1 - Voluntary party activity by Labour employees

Q. How active a member would you say you were prior to your employment with the Party?

Very active

Active

Occasionally active

Mainly or entirely inactive

Not sure/can't recall

$\%$

67

19

8

5
1

Note: $n=96$.

Table 2 - Party employees and elective politics

\section{Elective Office}

A parliamentary candidate

A European parliamentary candidate

A local councillor

A candidate for Scottish Parliament/Welsh Assembly

Total of the above (\%)

Note: $n=96$ unless marked with an asterisk, in which case $n=47$.

\begin{tabular}{|c|c|c|}
\hline $\begin{array}{l}\% \text { which has } \\
\text { already } \\
\text { attempted }\end{array}$ & & $\begin{array}{l}\% \text { intending to } \\
\text { seek future } \\
\text { selection as: } *\end{array}$ \\
\hline & 9 & 20 \\
\hline & 4 & 11 \\
\hline & 38 & 28 \\
\hline & 4 & 2 \\
\hline & 55 & 61 \\
\hline
\end{tabular}


Table 3 - Social Background of Labour Employees, Members and Voters

Employees Members Voters

Average age

38

51

48

Sex

Male

Female

53

61

46

Class ID

Yes

No

Which Class ID?

Middle

Working

Other

\section{Education}

Postgraduate

Degree

HND/OND

A Level/Equivalent

O Level/Equivalent

Other/None

\section{Ethnicity}

\section{White}

Black: Afro/Carib.

Black: Asian

Other

Union member

Yes

No

Previous Trade Union Employee

Yes

No
47

39

54

61

39

$37 \quad 29 \quad 39$

$53 \quad 29 \quad 24$

$\begin{array}{lll}42 & 71 & 76\end{array}$

(an)

20 n/a n/a

$\begin{array}{lll}51 & 21 & 10 \\ 1 / \mathrm{a} & 19 & 10\end{array}$

$\begin{array}{lrr}7 & 8 & 12\end{array}$

$\begin{array}{lll}10 & 26 & 29\end{array}$

$\begin{array}{lll}13 & 27 & 41\end{array}$

$93 \quad 94 \quad 94$

$\begin{array}{lll}2 & 3 & 2\end{array}$

$\begin{array}{lll}1 & 3 & 3 \\ 4 & 0 & 1\end{array}$

$96 \quad 41 \quad 26$

$\begin{array}{lll}4 & 59 & 74\end{array}$

13 n/a n/a

87 n/a n n

Note: All figures except for average age are percentages.

Data sources: Labour Employees Survey 2000 (n=96); British Election Survey 1997 (n=1367); and Labour Membership Survey 1997 $(\mathrm{n}=5761)$. We are grateful to Paul Whiteley and Patrick Seyd for making the latter data set available to us. 
Table 4 - General incentives for party employment

Incentive/disincentive

\section{Perception of influence}

Working for the Party means that I can have a real influence on the Party's success *

\section{Selective costs}

I could earn more money doing similar work for another employer $* *$

Party employees are often unappreciated by leading party politicians *

Selective process benefits

Working for the Party is much more fulfilling than working elsewhere **

Working for the Party allows me to work with likeminded people **

Selective outcome benefits

Working for the Party is good for my chosen career **

People like me would make excellent MPs *

Intend to stand for Parliament *\#

\section{Altruism}

Working for the Party means that democracy will be enhanced **
Disagree/

Disagree strongly \%

Notes: $* * \mathrm{n}=96, * \mathrm{n}=47$. \# indicates the percentage of respondents answering 'yes' to the question 'do you intend to seek future selection as...?' 


\section{Table 5 - Collective incentives for party employment}

\section{Left-Right Attitudes}

Ordinary people get their fair share of the nation's wealth*

It is government's responsibility to provide a job for everybody who wants one*

Private enterprise is the best way to solve Britain's economic problems

Major public services \& industries ought to be in state ownership*

There is one law for the rich and one for the poor

There is no need for strong trade unions to protect employees' working conditions \& wages

\section{Average}

\section{Libertarian-Authoritarian Attitudes}

Even parties which wish to overthrow democracy should not be banned

Censorship of films \& magazines is necessary to uphold moral standards

Homosexual relations are always wrong

People should be allowed to organize public meetings to protest against the government

People in Britain should be more tolerant of those who lead unconventional lives

Young people today don't have enough respect for traditional British values

$$
\text { Average }
$$

\section{Postmaterialist-Materialist Attitudes}

$\%$ Postmaterialist - \% Materialist

\section{European Integration Attitudes}

\author{
11-point scale, low score $=$ pro-integration
}

\section{MPs Members}

Voters

$\begin{array}{rrrr}56 & 88 & 85 & 67 \\ 9 & 26 & 59 & 58 \\ 30 & 33 & 37 & 31 \\ -11 & 26 & 70 & 34 \\ 21 & 87 & 79 & 77 \\ 96 & 82 & 61 & 52 \\ 33.5 & 57.0 & 65.2 & 53.2\end{array}$

$\begin{array}{rrrr}-6 & -10 & -27 & -37 \\ 36 & 5 & -44 & -49 \\ 94 & 88 & 15 & 19 \\ 100 & 98 & 78 & 66 \\ 96 & 91 & 46 & 38 \\ 35 & 13 & -36 & -53 \\ 59.2 & 47.5 & 5.3 & -2.7\end{array}$

Notes: 'Left' scores are calculated by adding together the percentage of respondents agreeing/agreeing strongly with a left-wing statement, or disagreeing/disagreeing strongly with a right-wing statement. 'Right' scores are calculated in a similar fashion in respect of right-wing statements, as are libertarian scores in respect of libertarian statements and authoritarian scores in respect of authoritarian statements. 'PDI' stands for percentage difference index: first devised by Norris (1996), this is calculated by subtracting the percentage of respondents favouring right-wing or authoritarian responses from the percentage favouring left-wing or libertarian responses; therefore, a positive figure represents a preponderance of left-wing or libertarian attitudes within the sample, while a negative figure represents a preponderance of right-wing or authoritarian attitudes. The questions are standard indicators of core values first devised and tested by Anthony Heath and colleagues (Heath et al 1993). Scores do not always total 100 since some respondents answered 'neither agree nor disagree' to questions.

Respondents are located on the materialist/post-materialist dimension through their responses to the classic Inglehartian question which requires respondents to prioritise their first and second most important policy objectives out of a list incorporating 'maintaining order in the nation', 'fighting rising prices', 'giving people more say in government decisions' and 'protecting freedom of speech'; while the former two options are taken to be indications of a materialist disposition, the latter two are indications of post-materialism.

Data Sources: Employees - Labour Party Employees Survey 2000 ( $n=47$ unless marked by an asterisk, in which case n=96; MPs - British Representation Survey 1997 ( $n=180)$; Members British Election Survey 1997 (n=66); Voters - British Election Survey 1997 (n=1367). 
1. The authors are grateful to the British Academy, which provided grant number APN8695 to facilitate this research.

2. For data sources see Webb (2000) p.193 and p.243.

3. We gratefully acknowledge all those Labour Party employees who have cooperated with us in this research, particularly those who gave their time to be interviewed. We especially appreciate the time and effort put in by the Party's Director of Personnel at Millbank, Jonathan Seller.

4. It is likely that the response rate suffered from the concerns shown by some party officials about the political sensitivity of this research project. Note that these concerns explain why the employees' sample size is considerably smaller in parts of Tables 2,4 and 5 than elsewhere. In general terms political parties are not surprisingly sensitive about research which is conducted into their employees, members or elected representatives. After some negotiation Millbank distributed a questionnaire approved by the General Secretary's office to employees at the beginning of 2000. Unfortunately, one unit at Millbank subsequently objected and the approval was rescinded; even so, some 47 employees (almost exactly half of our overall sample) completed and returned this questionnaire and we have incorporated these responses into the data set. After further negotiation, a slightly revised questionnaire was approved and once again distributed to staff. Clearly, this is less than ideal in terms of data quality; fortunately, however, comparison tests reveal little difference between the two 'half-samples' in the overall distribution of responses for the relevant variables. However, sample size for some variables is notably smaller than for others in Tables 2, 4 and 5 (that is, for variables which were included in the first questionnaire but excised from the second).

5. 54\% of our responses are from regional staff and $46 \%$ from the centre (Millbank staff and PLP officials). We believe this equates tolerably closely with a known population in which $52 \%$ of staff are located at the centre and $48 \%$ in the regions (Webb 2000: 243). In terms of its distribution across the grade structure: $11.1 \%$ of Millbank staff are currently employed at grades above 38 (that is, Head of Unit level) while some $9.9 \%$ of our sample is, and $45.3 \%$ of Millbank employees are graded below 38, compared with $43.7 \%$ of our sample. Unfortunately, we are unable to obtain a breakdown of regional employees by grade, so a comparison between known population characteristics and sample is only possible for Millbank employees.

6. Labour Party membership survey data 1997. These data were kindly provided by Paul Whiteley and Patrick Seyd

7. Interview conducted at Millbank, 3 March 2000.

8. Interview conducted at Millbank, 29 February 2000.

9. Interview conducted at Millbank, 12 November 1999.

10. The critical data constraint is that there is no variation in our dependent variable. Where, for instance, Seyd \& Whiteley were able to develop multiple regression models of activism among members using an 'index of activism' as the dependent variable, we are interested in explaining 'party employment' where there are no alternatives to party employees in the data set. It is impossible to utilise multivariate techniques such as regression analysis under these circumstances.

11. Labour Party Membership Survey 1997.

12. Interview conducted at Millbank, 3 March 2000.

13. Interview conducted at Millbank, 22 November 1999.

14. Interview conducted at Millbank, 22 November 1999.

15. Interview conducted at Millbank, 11 November 1999. 
16. Interview conducted at Millbank, 20 August 1999.

17 Labour Party Membership Survey 1997.

18. Interview conducted at Millbank, 11 November 1999.

19. Interview conducted at Millbank, 20 August 2000.

20. Interview conducted at Millbank, 11 November 1999.

21. Samples of party members and voters are drawn from the 1997 British Election Survey, while a sample of Labour MPs is taken the 1997 British Representation Survey. This is not ideal for two reasons. First, it would be preferable for all data to be collected simultaneously. However, since there is no comparable survey in 2000 , this is not possible. Nevertheless, data from 1997 should still provide a reasonable comparative impression. Second, by using the BES, the number of cases of Labour members is limited; we are unable to use the full party membership survey since comparable questions were not asked. That said, sample sizes of this magnitude have been successfully analysed in the past (Seyd \& Whiteley 1992; Webb \& Farrell 1999), so again, such data should be sufficient for us to derive a broad impression.

22. Not that electoral and policy motivations need be mutually incompatible; it is plainly consistent for a rational actor to seek electoral success as a prerequisite of achieving policy goals, the former being an instrumental motivation, the latter being intrinsically desirable (Mueller \& Strom 1999: 10-11). 